\title{
Recommendations for a safety dental care management during SARS-CoV-2 pandemic
}

\author{
Paulo Ricardo Martins-Filho ${ }^{1}$, Vanessa Tavares de Gois-Santos ${ }^{1}$, Carolina Santos Souza Tavares ${ }^{1}$, \\ Elisama Gomes Magalhães de Melo ${ }^{1}$, Edmundo Marques do Nascimento-Júnior ${ }^{1}$ and Victor \\ Santana Santos ${ }^{2}$
}

Suggested citation Martins-Filho PR, Gois-Santos VT, Tavares CSS, Melo EGM, Nascimento-Júnior EM and Santos VS. Recommendations for a safety dental care management during SARS-CoV-2 pandemic. Rev Panam Salud Publica. 2020;44:e51. https://doi. org/10.26633/RPSP.2020.51

\begin{abstract}
As the severe acute respiratory syndrome coronavirus 2 (SARS-CoV-2) is transmitted mainly through droplets, sneezes and aerosols, there is a high risk of transmission during dental procedures. This report describes measures that can be adopted by oral healthcare personnel to minimize the risk of cross-contamination in clinical practice during the current SARS-CoV-2 pandemic.
\end{abstract}

Keywords Coronavirus infection; virus diseases; pneumonia, viral; pandemics; dental care; SARS virus.

Evidence has emerged on the human-to-human transmission of the severe acute respiratory coronavirus 2 (SARS-CoV-2) in health care and family settings (1). As the virus spreads mainly through droplets, sneezes and aerosols (1), there is a high risk of transmission of SARS-CoV-2 during dental procedures (2). Recently, it was found that SARS-CoV-2 could be detected in saliva specimens which may allow viral transmission even among patients without cough or other respiratory symptoms (3). This report provides important recommendations based on the best available current evidence as well as lessons (4-7) from Severe Acute Respiratory Syndrome (SARS, 2003) and Middle East Respiratory Syndrome (MERS, 2012) epidemics for a safety dental care management during the current SARS-CoV-2 pandemic.

First, oral health care providers should prioritize urgent and emergent situations, such as pulpitis, pericoronitis, osteitis, abscess or localized bacterial infection, dental trauma, extensive caries or defective or broken restorations that cause pain or tissue damage, removal of sutures, adjustments in dentures and appliances that cause damage to oral structures and replacement of temporary filling in the endodontic access openings in patients with pain (8). Cosmetic and other elective dental procedures (9), such as orthodontic therapy, replacement of amalgam restorations for esthetic reasons, elective periodontal care, intentional root canal treatment, prosthodontics, or elective oral surgeries, should be postponed (10).

Second, it is crucial to avoid overcrowding in circulation areas and waiting rooms, since there is evidence that the close contact between susceptive individuals and infected individuals (being within about $1.8 \mathrm{~m}$ or within the room or care area of a confirmed COVID-19 case) increase the risk for SARS$\mathrm{CoV}-2$ infection (11). This may require an important change of habit in dental offices, where patients are often scheduled on a first-come, first-served basis, causing crowding. At this time, it is of fundamental importance that patients are scheduled by appointment, with a safety time frame between dental consultations, preventing contact or even proximity with other patients.

Third, the need for urgent dental care should be evaluated on a case-by-case basis and life- threatening cases should be admitted in a hospital. In case of urgent dental care, the main following measures targeted toward prevention by respiratory droplet and contact transmission should be adopted:

\footnotetext{
1 Federal University of Sergipe, Sao Cristovao, Brazil $₫$ Paulo Ricardo MartinsFilho, saqmartins@hotmail.com
} 
- To assess suspected patients through their signs and symptoms, especially fever and cough (12). In these cases, dental procedures should be postponed, and health authorities should be notified. Symptomatic relief for patients with tooth pain and/or swelling could be performed with analgesics such as acetaminophen. Although it was hypothesized a potential interaction between ibuprofen use and SARS-CoV-2 (13), there is no current evidence that this drug aggravates COVID-19 infection in any age group. Recently, the World Health Organization disclaimed there is contraindication for the use of ibuprofen in patients with COVID-19.

- To provide staff education and the use of Personal Protective Equipment (PPE) including N95 respirators, clinical gloves, safety glasses, hair covers and disposable aprons. A N95 respirator is a respiratory protective device designed to achieve a very close facial fit and very efficient filtration of airborne particles. N95 respirators block at least 95\% of very small (0.3 micron) test particles. A surgical mask is a loose-fitting, disposable device that creates a physical barrier between the mouth and nose of the wearer and potential contaminants in the immediate environment (14). Current evidence shows that N95 respirators appeared to have a protective advantage over surgical masks in laboratory settings and on procedures that generate aerosols, but the results from clinical studies are inconclusive regarding acute respiratory infections $(15,16)$. For patients in health facilities, the use of surgical masks seems rational (17).

- To clean hands with soap and water or hand rub with $70 \%$ ethanol or 70\% isopropanol (18), before and after assistance. Avoid touching eyes, nose, or mouth with uncleaned hands. Although there are no current studies evaluating the effects of ethanol on SARS-CoV-2, previous studies have shown that hand rubs with $70 \%$ ethanol or $70 \%$ isopropanol are usually effective against enveloped viruses including SARS-CoV and MERS-CoV $(19,20)$.

- Extraoral radiographs and cone beam computed tomography are preferable over intraoral radiographs to prevent cough or vomiting reflexes and, consequently, aerosol generation. Moreover, during dental procedures it is recommended to avoid stimulate trigger zones (21) of cough and vomiting including base of the tongue, fauces, uvula, palate, and posterior pharyngeal wall.

- To use rubber dam isolation during dental procedures and avoid the use of ultrasonic and sonic scalers, air polishing, air-water syringe, air abrasion units, and rotary handpieces. In vitro study showed that the airborne material generated by using ultrasonic scaler can be spread for a distance of at least $20 \mathrm{~cm}$ from the operative site (22). Furthermore, the potential for the spread of an pathogen via an invisible aerosol must be recognized and minimized or eliminated to the greatest extent feasible within a clinical situation (23). Importantly, it was shown that droplet nuclei can remain suspended in the air for up to 30 minutes (24). Therefore, removing the mask before 30 minutes in this environment may increase the risk of contact with contaminated particles. Efficient removal of contaminated ambient air could include improvements in the general ventilation and the use of High-Volume Evacuator. To date, there is no evidence of clinical effectiveness of pre- and post-procedural rinse with antiseptic solutions for SARS-CoV-2.

- For both suspected or confirmed COVID-19 cases requiring urgent dental care (e.g., abscess drainage), especially for those who will undergo procedures that generate aerosols, it is necessary, if possible, to leave them for the end of the service shift and promote terminal disinfection after care to avoid contaminating others.

- To clean and disinfect environmental surfaces and patientcare equipment using hospital grade germicides (quaternary ammonium-based, phenol-based, and alcohol-based products), as the SARS-CoV-2 can survive for 72 hours on surfaces of stainless steel and plastic, 24 hours in cardboard and from 40 minutes to 2 hours 30 minutes in aerosolized form or in dust (25). Disinfection and sterilization of instruments should be performed using appropriate PPE and wellestablished techniques. Reinforce biosafety guidelines for auxiliary staff of dentists. It is important to keep an adequate time frame between consultations for a correct cleaning of the dental office structure.

- To dispose the waste from dental procedures in specific packages for infected waste. These must be replaced when reaching $2 / 3$ of their capacity or at least within 48 hours, or in compliance with the institution's infection control committee protocols, since the inadequate disposal offers high risk to ecological and public health (26).

At this moment, it is important to recognize that controlling the spread of SARS-CoV-2 requires effort and oral health care providers may play an important role against this pandemic. Biosafety protocols and specific COVID-19protective measures must be strictly followed in case of need of urgent dental care.

\section{Conflict of interest. None declared.}

Disclaimer. Authors hold sole responsibility for the views expressed in the manuscript, which may not necessarily reflect the opinion or policy of the RPSP/PAJPH or the Pan American Health Organization (PAHO).

\section{REFERENCES}

1. Chan JF-W, Yuan S, Kok K-H, To KK-W, Chu H, Yang J, et al. A familial cluster of pneumonia associated with the 2019 novel coronavirus indicating person-to-person transmission: a study of a family cluster. Lancet. 2020;395(10223):514-23.

2. Peng X, Xu X, Li Y, Cheng L, Zhou X, Ren B. Transmission routes of 2019-nCoV and controls in dental practice. Int J Oral Sci [Internet]. 2020;12(1):9. Available from: http://www.ncbi.nlm.nih.gov/ pubmed/32127517
3. To KK-W, Tsang OT-Y, Chik-Yan Yip C, Chan K-H, Wu T-C, Chan JMC, et al. Consistent detection of 2019 novel coronavirus in saliva. Clin Infect Dis [Internet]. 2020 Feb 12; Available from: http:/ / www. ncbi.nlm.nih.gov/pubmed/32047895

4. Smales FC, Samaranyake LP. Maintaining dental education and specialist dental care during an outbreak of a new coronavirus infection. Part 2: Control of the disease, then elimination. Br Dent J. 2003;195(12):679-81. 
5. Li RWK, Leung KWC, Sun FCS, Samaranayake LP. Severe acute respiratory syndrome (SARS) and the GDP. Part II: implications for GDPs. Br Dent J. 2004;197(3):130-4.

6. Gaffar BO, El Tantawi M, Al-Ansari AA, AlAgl AS, Farooqi FA Almas KM. Knowledge and practices of dentists regarding MERSCoV. A cross-sectional survey in Saudi Arabia. Saudi Med J. 2019;40(7):714-20.

7. Al-Tawfiq JA, Perl TM. Middle East respiratory syndrome coronavirus in healthcare settings. Curr Opin Infect Dis [Internet]. 2015;28(4):392-6. Available from: http://www.ncbi.nlm.nih.gov/ pubmed $/ 26103552$

8. American Dental Association. What Constitutes a Dental Emergency? [Internet]. 2020 [cited 2020 Apr 9]. Available from: https:// success.ada.org/ /media/CPS/Files/Open Files/ADA_COVID19_ Dental_Emergency_DDS.pdf

9. Christensen GJ. Elective vs. mandatory dentistry. J Am Dent Assoc [Internet]. 2000;131(10):1496-8. Available from: http://www.ncbi. nlm.nih.gov/pubmed/11042991

10. CDC Recommendation: Postpone Non-Urgent Dental Procedures, Surgeries, and Visits [Internet]. 2020. Available from: https:/ /www. cdc.gov/oralhealth/infectioncontrol/statement-COVID.html

11. Ghinai I, McPherson TD, Hunter JC, Kirking HL, Christiansen D, Joshi K, et al. First known person-to-person transmission of severe acute respiratory syndrome coronavirus 2 (SARS-CoV-2) in the USA. Lancet [Internet]. 2020 Mar 13; Available from: http://www. ncbi.nlm.nih.gov/pubmed/32178768

12. Zhao D, Yao F, Wang L, Zheng L, Gao Y, Ye J, et al. A comparative study on the clinical features of COVID-19 pneumonia to other pneumonias. Clin Infect Dis [Internet]. 2020 Mar 12; Available from: http://www.ncbi.nlm.nih.gov/pubmed/32161968

13. Day M. Covid-19: ibuprofen should not be used for managing symptoms, say doctors and scientists. BMJ [Internet]. 2020;368:m1086. Available from: http:/ / www.ncbi.nlm.nih.gov/pubmed/32184201

14. U.S. Food \& Drug Administration. N95 Respirators and Surgical Masks (Face Masks) [Internet]. 2020 [cited 2020 Apr 9]. Available from: https://www.fda.gov/medical-devices/personalprotective-equipment-infection-control/n95-respiratorsand-surgical-masks-face-masks

15. Offeddu V, Yung CF, Low MSF, Tam CC. Effectiveness of Masks and Respirators Against Respiratory Infections in Healthcare Workers: A Systematic Review and Meta-Analysis. Clin Infect Dis [Internet]. 2017 Nov 13;65(11):1934-42. Available from: http:/ / www.ncbi.nlm. nih.gov/pubmed/29140516

16. Smith JD, MacDougall CC, Johnstone J, Copes RA, Schwartz B, Garber GE. Effectiveness of N95 respirators versus surgical masks in protecting health care workers from acute respiratory infection: a systematic review and meta-analysis. Can Med Assoc J [Internet]. 2016 May 17;188(8):567-74. Available from: http://www.ncbi.nlm. nih.gov/pubmed/26952529
17. Feng S, Shen C, Xia N, Song W, Fan M, Cowling BJ. Rational use of face masks in the COVID-19 pandemic. Lancet Respir Med [Internet]. 2020 Mar 20; Available from: http://www.ncbi.nlm.nih.gov/ pubmed /32203710

18. Centers for Disease Control and Prevention. CDC Statement for Healthcare Personnel on Hand Hygiene during the Response to the International Emergence of COVID-19 [Internet]. 2020 [cited 2020 Apr 9]. Available from: https://www.cdc.gov/coronavirus/2019-ncov/ hcp/hand-hygiene.html?CDC_AA_refVal=https $\% 3 \mathrm{~A} \% 2 \mathrm{~F} \% 2 \mathrm{Fwww}$. cdc.gov\%2Fcoronavirus $\% 2$ F2019-ncov\%2Finfection-control $\% 2 \mathrm{Fh}$ cp-hand-sanitizer.html

19. Kariwa H, Fujii N, Takashima I. Inactivation of SARS coronavirus by means of povidone-iodine, physical conditions and chemical reagents. Dermatology [Internet]. 2006;212 Suppl:119-23. Available from: http:/ / www.ncbi.nlm.nih.gov / pubmed/16490989

20. Kampf G. Efficacy of ethanol against viruses in hand disinfection. J Hosp Infect [Internet]. 2018 Apr;98(4):331-8. Available from: http:/ / www.ncbi.nlm.nih.gov/pubmed/28882643

21. Meeker HG, Magalee R. The conservative management of the gag reflex in full denture patients. N Y State Dent J [Internet]. 1986 Apr;52(4):11-4. Available from: http://www.ncbi.nlm.nih.gov/ pubmed/3457325

22. Harrel SK, Barnes JB, Rivera-Hidalgo F. Aerosol and splatter contamination from the operative site during ultrasonic scaling. J Am Dent Assoc [Internet]. 1998 Sep;129(9):1241-9. Available from: https://linkinghub.elsevier.com/retrieve/pii/S0002817714 662656

23. Harrel SK, Molinari J. Aerosols and splatter in dentistry: a brief review of the literature and infection control implications. J Am Dent Assoc [Internet]. 2004 Apr;135(4):429-37. Available from: http:/ / www.ncbi.nlm.nih.gov/pubmed/15127864

24. Larato DC, Ruskin PF, Martin A, Delanko R. Effect of a dental air turbine drill on the bacterial counts in air. J Prosthet Dent [Internet] 1966 Jul;16(4):758-65. Available from: https://linkinghub.elsevier. com/retrieve/pii/0022391366901570

25. van Doremalen N, Bushmaker T, Morris D, Holbrook M, Gamble A, Williamson B, et al. Aerosol and Surface Stability of SARS-CoV-2 as Compared with SARS-CoV-1. N Engl J Med. 2020 Mar;NEJMc2004973.

26. Muhamedagic B, Muhamedagic L, Masic I. Dental office waste public health and ecological risk. Mater SocioMed. 2009;21(1):35-8.

Manuscript received on 26 March 2020. Revised version accepted for publication on 10 April 2020. 


\section{Recomendaciones para una atención odontológica segura durante la pandemia por SARS-CoV-2}

RESUMEN Dado que el SARS-CoV-2, causante de síndrome respiratorio agudo severo, se transmite principalmente por medio de gotitas, estornudos y aerosoles, existe un alto riesgo de transmisión durante los procedimientos dentales. En este informe se describen las medidas que puede adoptar el personal de salud bucodental para reducir al mínimo el riesgo de contaminación cruzada en la práctica clínica durante la actual pandemia por SARS-CoV-2.

Palabras clave Infecciones por coronavirus; virosis; pandemias; asistencia odontológica; virus del SRAS.

\section{Recomendações para um atendimento odontológico seguro durante a pandemia do SARS-CoV-2}

RESUMO

Como o SARS-CoV-2, que causa síndrome respiratória aguda grave, é transmitido principalmente por gotículas, espirros e aerossóis, há um alto risco de transmissão durante os procedimentos odontológicos. Este relatório descreve os passos que podem ser tomados pelo pessoal de saúde oral para minimizar o risco de contaminação cruzada na prática clínica durante a actual pandemia do SARS-CoV-2.

Palavras-chave Infecções por coronavirus; viroses; pandemias; assistência odontológica; vírus da SARS. 